\title{
ICТОРІЯ УКРАÏНИ
}

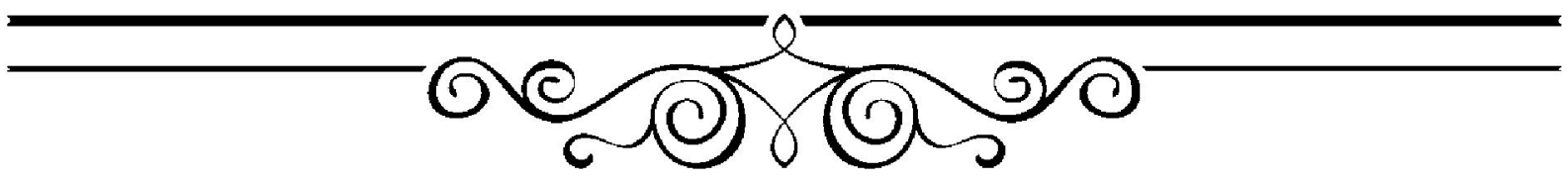

УДК 477.4:058.244«1800-1917»

DOI: 10.31651/2076-5908-2019-1-38-44

\author{
ПЛАТМІР Ярослав Леонідович, \\ аспірант кафедри Історії України \\ Черкаського національного університету \\ імені Богдана Хмельницького, \\ Orcid ID: 0000-0001-8205-7286 \\ e-mail: metsepman91@gmail.com
}

\section{УКРӒ̈НСЬКА ІНТЕЛІГЕНЦІЯ «ДОВГОГО» ХІХ СТ.: СУСПІЛЬНІ РОЛІ ТА ОСНОВНІ ТЕНДЕНЦІЇ ЇХНЬОЇ ТРАНСФОРМАЦЇ̈}

«Довге ХІХ століття» було прочесом формування модерної украӥнської нації під владою Романових та Габсбургів. Не зважаючи на складнощі, котрі поставали перед украйнською (в намому дослідженні-наддніпрянською) інтелігенцією, їй доводилося йти на певні компроміси з владою та чиновниками задля розбудови підвалин для власної державності в майбутньому.

Перебуваючи під впливом європейських ідей демократизму та лібералізму украӥнська інтелігенція не стала буржуазією. Ї̈ строкатий склад засвідчував лиш те, що вона була досить несталим суспільним прошарком, як от селянство та дворянство. До міської інтелігениіі додається ще й селянська, котра не мали великих землеволодінь та займалася розумовою працею. В статті наведено певний розподіл і між самою інтелігенцією та досліджено трансформацію изого суспільного прошарку.

Ключові слова: інтелігенція, селянство, дворянство, Наддніпрянщина, суспільство.

Постановка проблеми. Протягом XIX ст. соціальна структура українського (наддніпрянського) суспільства зазнала істотної трансформації. Вона була зумовлена загальними змінами, які отримали в історіографії неоднозначні інтерпретації й оцінки. Серед інших чи не найчастіше вживається поняття «модернізація», що включає в себе складні процеси соціальних пертурбацій, пов'язаних із промисловим переворотом, урбанізацією, індустріалізацією, кооперацією, капіталізацією всіх сфер життєдіяльності, демографічним «вибухом». Унаслідок цих змін повністю сформованою наприкінці XIX ст., окремою соціальною верствою населення стала інтелігенція. На початку XX ст. вона вже займала місце рушійної сили в багатьох процесах бурхливого життя. Щодо української інтелігенції, то іiї головним завданням (під впливом тих же модернізаційних змін) стало утвердження в свідомості спільноти власної національної ідентичності. 
Окрім культурної та етнонаціональної (інтелектуально-функціональної) ролі інтелігенції, вона отримала наприкінці XIX - на початку XX ст. й інше завдання політичне. Його сутність полягала в тому, щоб напрацювати нові (модерні) алгоритми пояснення та перспектив розвитку суспільства («народу»). Незважаючи на жорстку протидію з боку державницько-імперської політики офіційного Санкт-Петербургу та його численних виконавців на регіональному рівні, котрі прагнули звести все «українське питання» до поняття/явища «Малоросія» («малороси»), свідома наддніпрянська інтелігенція не лише не стояла осторонь цих процесів, а й чітко визначилися з власне національними пріоритетами та перспективами. Слова М. Грушевського «хто такі українці й чого вони хочуть» переконливо підтверджують актуальність запропонованих тут міркувань [1, 152-164].

Аналіз останніх досліджень і публікацій. Варто зауважити, що пропонована проблематика досліджена досить грунтовно, але не всі їі аспекти розкриті повністю. Про структуру, національний склад, рід занять інтелігенції писали Я. Грицак («Нариси з історії України: формування української модерної нації»), Г. Касьянов («Українська інтелігенція на рубежі XIX-XX століть: соціально-політичний портрет»), О. Реєнт («Україна в імперську добу (XIX - початок XX ст.)). Водночас, про модернізаційні процеси на українських землях, зокрема в Наддніпрянщині, докладно йдеться в колективній монографії В. Шандри, I. Гирича, I. Монолатія, А. Галушка, І. Глизя, В. Масненка, Ю. Присяжнюка, С. Шамари («У кігтях двоглавих орлів. Творення модерної нації. Україна під скіпетрами Романових і Габсбургів»). Проте суспільні ролі та основні тенденції їхньої трансформації не знайшли висвітлення з названих та інших працях.

Мета статті полягає в розширенні та поглибленні дослідницького поля, предметом якого є суспільні ролі української інтелігенції Наддніпрянщини, що постала в історичних умовах модернізації XIX - початку XX ст.

Виклад основного матеріалу. Отже, помітне i, як з'ясовується, особливе місце в соціальній структурі Наддніпрянської України XIX - початку XX ст. займала інтелігенція. Ким вона була представлена? Більшість дослідників відносять до цього прошарку людей, які професійно займалися розумовою працею, а точніше - трьома іï видами: по-перше, власне інтелектуальною діяльністю, продукт якої став(вав) товаром і водночас мав духовну цінність (наприклад твори письменників, художників), по-друге, діяльністю, яка поєднувала результат «не-інтелектуальної» праці з творчим процесом (робота вчителів, лікарів, статистиків) та, по-третє, розумовою діяльністю, унаслідок якої створювалися матеріальні цінності (приміром, праця інженерів). «Соціально-економічно» інтелігенція відрізнялася від дворян (поміщиків) відсутністю аристократичного «коріння», також, як правило, власності на засоби виробництва, а від робітників і селян тим, що ії представники займалися не фізичною, а розумовою працею. Зважаючи на історичні особливості тогочасного суспільства, його, так би мовити, «перехідний» характер, інтелігенція набула специфічних гетеро- та авто-стереотипних образів у поглядах решти населення. Скажімо, багатомільйонне селянство сприймало іï як прошарок «панства», хоча ступінь довіри в цьому випадку був набагато більшим.

У великій історичній перспективі саме ХІХ ст. стало переломним етапом у формування нової (модерної) соціальної сутності інтелігенції. Головними рисами іiї становлення й розвитку можна вважати такі: по-перше, чисельне зростання, особливо інтенсивне в другій половині «історичного» століття (фактично кожна наступна генерація інтелектуалів могла тут похвалитися новими рекордами); по-друге, трансформація соціальних джерел формування, що своєю чергою було обумовлено демократизацією її складу; по-третє, колосальне зростання впливу прошарку інтелектуалів на суспільно-політичне життя; по- 
четверте, остаточне оформлення інтелігенції в окрему, специфічну соціально-професійну верству.

Унаслідок різного соціального походження, матеріального становища та правового статусу інтелігенція, усе ж, не була такою монолітною суспільною групою, як це було 3 «традиційними» верствами - дворянством, селянством, духівництвом, купецтвом та ін. Найбільш кваліфіковані (порівняно освіченіші) представники розумової праці - науковці (професори), видатні інженери, агрономи, письменники, актори, художники та інші становили найменш численну частину та, своєю чергою, найбільш привілейовану підгрупу. Водночас, наймасовішою їі частиною були особи, що здійснювали порівняно нескладну виконавчу роботу, яка не вимагала серйозної освіти й включала в себе елементи фізичної праці (канцеляристи, службовці пошти, телеграфу, фельдшери, техніки та ін.). Також було багато державних і приватних службовців [2, 34-35].

У контексті національних процесів розвиток української інтелігенції відбувався в складних умовах, адже тривала перманентна боротьба за саму можливість існування національної духовної і політичної еліти. Серед політичних ідей, які проголосила ця інтелектуально-політична еліта, найвагомішими були ті, що виявилися пов'язаними 3 потребою об'єднання нації, створення власної (бодай і автономної) державності. Слова I. Франка слугують тут своєрідним маніфестом для тогочасної інтелігенції, водночас критерієм оцінки іiі для сучасного пізнавального схоплення: «Перед українською інтелігенцією відкривається тепер, при свобідніших формах життя... величезна дійова задача - витворити з величезної етнічної маси українського народу українську націю, суцільний культурний організм, здібний до самостійного культурного й політичного життя, відпорний на асиміляційну роботу інших націй, відки б вона не йшла, та при тім податний на присвоювання собі в якнайширшій мірі і в якнайшвидшім темпі загальнолюдських культурних здобутків, без яких сьогодні жодна нація і жодна хоч і не сильна держава не може остоятися» $[3,50]$.

Загальне розуміння українською інтелігенцією своєї суспільної (історичної) ролі та власної слабкості (насамперед через нечисленність) спонукало зусилля до створення національних навчальних і наукових закладів, породжувало численні спроби реформування освітньої сфери. Навчальний процес, який визначав «підготовчий» процес формування інтелігенції, лишався далеко не системним. Напрочуд малий відсоток українських студентів навчалися повний термін (ця ж обставина була характерною і для учнів початкових шкіл, гімназій, ремісничих училищ). До того ж, русифікаторські процеси, особливо з виданням Валуєвського циркуляру (1863) та Емського указу (1876), надзвичайно пришвидшувалися. Власне тому гурти студентів, які ідентифікували себе «українцями» й здобували знання в кращих європейських і російських навчальних закладах, вирізнялися більшою національною свідомістю; передусім вони готувалися до того, аби заповнити вакансії в українській науці та культурі. Оскільки багато студентів походило з сільської місцевості, ці молоді люди здебільшого щиро прагнули покращити долю своїх односельців. Вони і в студентські роки, і згодом працювали на культурно-освітній ниві в читальнях, кооперативах, аматорських гуртках, театрах тощо. Наприкінці XIX - на початку XX ст. формується нове покоління молодих українських діячів, котрі вже не вагалися щодо власної національної ідентичності та самобутності, ба більше, рішуче вимагали для свого народу національних прав і політичних свобод $[4,232]$.

Протягом XIX - початку XX ст. українська інтелігенція не була позбавлена такого традиційного «недуга» як конфлікт поколінь $[5,9]$. Значною мірою він був спричинений зміною епох, що привносило свій колорит, зокрема й у персональні та родинні взаємини. Часто молодь керувалася прямо протилежними починаннями: аби «відійти» від минулого, 
порівняно радикальніше тяжіла до нового (на що свого часу звертав увагу П. Куліш) [5, 8]. За словами I. Лисяка-Рудницького, це передусім відображалося в критичному сприйнятті нащадків провідних верств, що стояли в той час на грунті чужих державних ідеологій. «Традиційна» ж інтелігенція не лише мало що робила, щоб ці молодіжні суспільні групи схилити до української справи, а навпаки, чинила все можливе, аби мінімізувати їхню публічну діяльність. Навіть окремі постаті зі старої генерації, котрі дотримувалися «шляхетного ідеалізму» щодо українства, отримували недовір'я. Таке ставлення інтелігенції не могло задовольнити й самі молоді активні сили, що кооптувалися «з народу», i, не маючи змоги вгамувати свої стихійні прагнення в українських формах, поповнювали російську імперську intelligibility [6, 364].

Отже, формування модерної нації протягом XIX ст. в умовах утвердження в Російській імперії індустріального суспільства викликало до життя інтелігенцію як специфічного суспільного прошарку. І. Коляда ділить тогочасну інтелігенцію на три групи. До першої групи відносить представників розумової праці, які намагалися соціально-активною діяльністю пробудити до життя сталі українські традиції, звичаї, можливо - ментальні архетипи способом поширення ідеї української самобутності, роблячи акцент на політичній сфері. Другу становила та частина інтелігенції, яка діяла в руслі, що був заданий російською ліберально-земськими діячами, котрі в самобутніх умовах Російської імперії були класичною опозицією самодержавству, охоплюючи насамперед регіональний рівень. Вона сприяла також утвердженню новітніх засад професійної діяльності та етики на противагу прямому пристосуванству й прислужництву, як наслідок - репрезентувала чиновницьку опозицію. До третьої І. Коляда відніс тих інтелектуалів, які своєю життєвою позицією підтверджували лояльність і «були відкритими до російського самодержавства» [7, 212].

Запропонований I. Колядою поділ підтверджує думку про відсутність тотальної ролі інтелігенції в розгортанні національних процесів на початку ХХ ст., навіть більше, ставить під сумнів іiі адекватне реагування на кризові явища. Це були, так би мовити, «зовнішні» складові процесу трансформації української інтелігенції в політичну еліту. Його внутрішню сутність визначав розвиток її політичної свідомості, який виявлявся в тому, що національний рух грунтувався на інтересах далеко не однієї верстви.

Українська національна інтелігенція початку XX ст., до того часу сприйнявши західну ліберальну й демократичну ідеї, а також спираючись та критично переосмислений український історичний досвід (що було притаманно відносно вузькому колу інтелектуалів), не стала буржуазією. Радше навпаки, зберігалася «закоріненість» у європейську інтелектуальну і культурно-політичну традицію. Унаслідок участі в інституціоналізації та діяльності політичних партій і організацій вона додавала до своєї професійної, корпоративної, соціальної характеристик інтелектуальну елітарність.

На противагу російській (налаштованої на імперські цінності та пріоритети), українська інтелігенція помітно інакше змінювала свої світоглядні акценти. Якщо росіяни акцентували увагу на «спасінні» й не «прищеплювали» селянам істинної свободи, то українці підросійської Наддніпрянщині - на звільненні, що виявилося в ідеї української державності. Протягом XIX ст. українська інтелігенція від перших своїх суспільних кроків (діяльність І. Котляревського, Є. Гребінки, М. Маркевича, М. Остроградського та ін.) проводила широке культурництво. По суті перманентно перебуваючи в «недружньому» середовищі, вона була покликана протистояти набагато численнішим соціальним верствам, для яких асиміляторська політика самодержавства лишалася «звичною справою». Це вносило відчутний психологічний дисбаланс між національними та соціальними пріоритетами (завданнями) - з одного боку, прагнення до соціального достатку й землі (у селян), достойної оплати праці - в найманих робітників, з іншого, покликання творення 
національного життя - від історичної пам'яті, мови, культури, до державності. Цю невизначеність підживлювала залежність від насправді потужного російського впливу, який на свій лад розставляв акценти соціального й національного. Генерації українських інтелектуалів початку XX ст. виявляться «гідними спадкоємцями» цієї підпорядкованості [7, 213-214].

Також цікавою для розуміння тих процесів є сільська інтелігенція, котра почала формуватися в другій половині XIX ст. Основними навчальними закладами, що готували «нове панство» для села, були духовні семінарії. Випускники міських гімназій, ліцеїв, учительських семінарій, педагогічних курсів та інших закладів середньої (та нижчої середньої) освіти, також особи, які здобували домашню освіту, становили ще більший ресурс поповнення сільської інтелігенції. Але «не всі вони йшли працювати в села» $[8,72]$.

Освітні контрреформи 1870-1880-х рр. не давали змогу вступити в університети людям, котрі не мали диплому класичної гімназії, представляли соціальне дно суспільства. Тому кадри сільської інтелігенції Наддніпрянщини поповнювали переважно ті особи, які закінчували міські училища, гімназії чи духовні семінарії, водночас не змогли вступити до університетів у зв'язку з урядовими заборонами або іншими обставинами. 3 незадоволеними амбіціями такі спеціалісти поверталися на село. Серед них було багато таких, котрі не закінчили повний курс навчання.

На формування ідентичності інтелігенції вплинув ліберальний дух реформ 18601870-х рр. Зміни у характері економічної діяльності означали, що отримавши освіту, фахівці виходили у світ професій, який ставав дедалі різноманітнішим. Державна служба уже не була єдиним засобом пристойного заробітку. В умовах ринкових відносин було закладено умови для появи когорти вільнодумних людей, котрі самі вирішували, як надалі будувати своє життя та на яку роботу влаштовуватися. Походження й сімейні статки дедалі менше відігравали роль, натомість більше цінувалися професійні уміння та здібності.

Сільська інтелігенція формувалася у специфічних умовах. Потреба в новій системі державного регулювання призвела до зміни управлінської структури села. Новий формат економічної залежності селянства, який був передбачений Великою реформою 1861 р., суттєво розширював попит на допомогу освічених людей. Зрештою, реформа початкової освіти і народолюбні аспірації «перших інтелігентів» призводили до розширення функцій «розумових людей» на селі. Місцеве духовенство, як і раніше, виступало моральним охоронцем старорежимних порядків. Водночас реформи ставили перед кліром низку додаткових обов'язків. Унаслідок суспільних трансформацій з'являлася нова когорта представників дворянства, яка не мала великих статків і земельної власності.

Саме декласований дворянський елемент, духовенство, заможне селянство, різноманітні міські прошарки поповнювали верству сільської інтелігенції. Ажіотаж навколо реформ спричинив до появи громадської думки, згідно з якою вважалося почесним працювати на селі. Прописка в сільській місцевості порівняно нової верстви породила також цікавий взаємообумовлений соціокультурний процес - так зване «оселянювання» інтелігенції і початок «інтелектуалізації» селян [7, 74-76].

Висновки. Протягом XIX ст. формувався новий прошарок суспільства - інтелігенція, котра працювала переважно в містах, але з роками виявляла дедалі більший інтерес до села. Це були люди розумової праці з різними статками та освітою, котрі брали на себе роль просвітників селянства. При цьому інтелігенція ще не була соціально однорідною за структурою, як, приміром, поміщицтво, хоча мала набагато вищий рівень довіри серед селян. Унаслідок подальших змін, на зламі XX ст. модернізаційні процеси вивели на історичну авансцену верству, котра, попри відсутність у неї значних фінансових накопичень 
і земельних угідь, помітно впливала на суспільну думку та багато інших процесів у різних сферах життєдіяльності підросійської України.

\section{Список використаної літератури}

1. Грушевський М. С. Хто такі українці і чого вони хочуть / М. С. Грушевський // Твори : у 50 т. ; Редкол. : П. Сохань (голов. ред.), Я. Дашкевич, І. Гирич та ін. - Львів : Вид-во «Світ», 2007. - Т. 4. - Кн. 1. - С. $152-164$.

2. Баличева Л. В. Еволюція соціальної структури інтелігенції Наддніпрянської України в XIX ст. / Л. В. Баличева // Збірник наукових праць Харківського національного університету ім. Г. С. Сковороди. Серія : Історія та географія. - 2013. - Вип. 47. - С. 33 - 37.

3. Див. : Що таке сучасний патріотизм узагалі й по-українськи? / Авт. і уклад. Ю. Присяжнюк. Черкаси : «Вертикаль», вид. П.П. Кандич С. Г., 2009. - 68 с.

4. Щербатюк Т. В. Формування інтелігенції як окремої верстви суспільства в Україні наприкінці XIX - початку XX ст. / Т. В. Щербатюк // Вісник Кам'янець-Подільського національного університету ім. І. Огієнка. Серія : Історичні науки. - 2010. - Вип. 3. - С. 229-235.

5. Кулиш П. Малороссийские предания и разные заметки, касающиеся местных примечательностей, обычаев и т. д. / П. Кулиш. - Кн. 1. Заметки этнографического характера. - 1843. - 9 л. / Відділ рукописів Інституту мистецтвознавства, фольклористики та етнології імені М. Рильського у м. Києві. - Ф. 3-2. - Спр. 116.

6. Лисяк-Рудницький І. Історичні есе. / І. Лисяк-Рудницький. - Т. 2. - К., Основи, 1994. - 573 с.

7. Коляда I. А. Інтелігенція та українська ідея в російському імперському суспільстві кінця XIX - початку XX ст. / I. А. Коляда // Наддніпрянська Україна : історичні процеси, події, постаті : зб. наук. пр. / Редкол. : С. І. Світленко (відп. ред.) та ін. - Д. : Вид-во ДДУ, 2007. Вип. 5 : Перші Всеукраїнські Яворницькі наукові читання. - С. 205-216.

8. Захаренко О. С. Соціально-психологічний аналіз політичних й економічних умов життєдіяльності сільської інтелігенції Наддніпрянської України у другій половині XIX - на початку XX ст. / О. С. Захаренко, С. О. Шамара // Вісник Черкаського університету. Серія : Історичні науки. - 2008. - №133-134. - С. $71-78$.

\section{References}

1. M. Hrushevsky (2007). Who are the Ukrainians and what do they want. Works in 50 vol., vol.4. book 1. Lviv, 152-164 (In Ukr.)

2. L. Balycheva (2013). The Evolution of social structure of intelligentsia of Naddnipryanschyna in Ukraine in XIX. The compilation of scientific works of H. Skovoroda Kharkiv National University. Series: History and Geography. Vol. 47. 33-47 (In Ukr.)

3. Y. Prysiazhniuk (2009). What is modern patriotism and in general and Ukrainian in particular?. Cherkasy, 68. (In Ukr.)

4. T. Scherbatiuk (2010). The Formation of intelligentsia as a separate stratum on society in Ukraine at the end of XIX - beginning of XX. Visnyk of I. Ogienko Kamianets-Podilskyi National University. Series: Historical sciences. Vol. 3. 229 - 235. (In Ukr.)

5. P. Kulish (1843). Malorussian legends and different notes considering local attractions, customs etc. Book 1 Notes of ethnographic nature. Department of scripts of M. Rylsky Institute of Arts, Folklore Studies, and Ethnology in Kyiv. Stock 3-2. Case 116. (In Russ.)

6. I. Lysiak-Rudnytskiy (1994). Hisorical Essays. Vol. 2. Kyiv, 573. (In Ukr.)

7. I. Koliada (2007). Intelligentsia and Ukrainian idea in Russian Imperial society at the end of XIX beginning of XX century.Ukrainian Naddnipryanschyna: historical processes, events, personalities. Compilation of scientific works. Editors: S. Svitlenko (chief ed.) and others. Dnipropetrovsk, vol. 5. The first All-Ukrainian Yavornytsky Scientific Readings. 205-216. (In Ukr.)

8. O. Zaharenko, S. Shamara (2008). Socio-psychological analysis of political and economic conditions of peasantry intelligentsia livelihoods in Ukrainian Naddnipryanschyna in the second part of XIX at the beginning of XX century. Visnyk of Cherkasy University. Series Historical sciences. №133134. 71- 78. (In Ukr.) 
PLATMIR Yaroslav, Postgraduate (History), Department of History of Ukraine, Bohdan Khmelnytsky National University of Cherkasy

\title{
UKRAINIAN INTELLIGENTSIA OF THE «LONG» NINETEENTH CENTURY: SOCIAL ROLES AND MAIN TENDENCIES OF THEIR TRANSFORMATION
}

\begin{abstract}
Introduction. The "Long" nineteenth century was the process of forming a modern Ukrainian nation under the rule of the Romanovs and Habsburgs. Notwithstanding the difficulties faced by Ukrainian (in our study - Naddniprianschyna) intelligentsia, it had to make some compromises with authorities and officials to build the foundations for her own statehood in the future.

Under the influence of European ideas of democracy and liberalism, Ukrainian intelligentsia did not become a bourgeoisie. Its diverse constituent certified only the fact of being unstable social stratum, as, for instance, peasantry or aristocracy. Peasantry intelligentsia is added to civic, which did not own large landholdings and was engaged in mental activities. The article provides us with a certain distribution among the intelligentsia itself and investigates the transformation of the given social stratum.
\end{abstract}

Purpose. It is important to mention that the evolution of Ukrainian national ideology took place under the influence of European ideas. They, however, captured the thoughts of very narrow circles of humanitarians, most of whom engaged in the study of ethnographic and folklore spheres of peasant life, and therefore, were concerned about a relatively limited range of issues. At the same time, the comprehension of the past and present problems arose against the background of the involvement of a new generation of public figures in the movement. In the territory of Naddnipryanschyna, it was formed in conditions of rapid modernization, while maintaining the imperial (autocratic) system of power.

Results. After analyzing all the main dimensions of the proposed problem, the author came to the conclusion that in relation to social processes (realities) at the beginning of the twentieth century in the Naddnipryanchyna, the Ukrainian intelligentsia focused on socio-cultural, national, regional, and, to a lesser extent, economic and social life. The choice between «culture and politics» was too limited.

Conclusion. In a situation, where many forces were in need to solve internal (party, interpersonal, etc.) problems, such a local orientation significantly weakened the influence of intellectual circles on society, particularly the peasantry. Meanwhile, when the Ukrainian intelligentsia claimed to be the main leading force of national affirmation, the establishment of bonds between the Western («sub-Austrian») and the eastern («sub-Russian») communities, it did little to impact on the general population, the common people that was a huge fallacy in the new historical conditions.

Key words: intelligentsia, peasantry, aristocracy, Naddniprianschyna, society. 